\title{
Micromorphology and anatomy of the leaf blade: a contribution to the taxonomy of Luziola (Poaceae, Oryzoideae) from the Pantanal, Brazil
}

\author{
Thales D. Leandro ${ }^{1} \cdot$ Edna Scremin-Dias $^{2} \cdot$ Rosani do Carmo de Oliveira Arruda ${ }^{2}$
}

Received: 5 January 2015/Accepted: 19 October 2015/Published online: 12 November 2015

(C) Springer-Verlag Wien 2015

\begin{abstract}
Luziola comprises nine monoecious, aquatic species and has its center of diversity in South America. Due to the morphological similarities among Luziola species in the vegetative stage, the micromorphology and anatomy of the leaf blade of five Luziola species were studied to survey potentially useful features for taxon identification. Oryzoid silica bodies; silicified unicellular trichomes with a rounded apex; stomata in furrows on the adaxial surface; a complex midrib consisting of at least two vascular bundles; superposed vascular bundles in the mesophyll; and fusoid cells are features shared by some of these species. Conversely, features unique to a single species include: vertically elongated epidermal cells surrounding pointed unicellular trichomes, flat midrib and leaf margin dimorphism (L. fragilis), and an obtuse leaf blade margin (L. subintegra). L. spruceana and $L$. subintegra show the greatest micromorphological and anatomical affinity among the five species herein studied, and $L$. fragilis has the greatest number of unique features. All species are recognized by the structure of the midrib, a strong feature for the identification of taxa within Luziola.
\end{abstract}

Handling editor: Karol Marhold.

Part of Master's Thesis research of the first author, Programa de PósGraduação em Biologia Vegetal, UFMS, Brazil.

Thales D. Leandro

thaleshdias@gmail.com

1 Universidade Estadual Paulista, Av. 24A 1515, Bela Vista, Rio Claro, SP 13506-900, Brazil

2 Universidade Federal de Mato Grosso do Sul, Av. Costa e Silva $s / n^{\circ}$, Caixa Postal 549, Cidade Universitária, Campo Grande, MS 79070-900, Brazil
A key for the identification of the studied species is presented based on the leaf blade features.

Keywords Aquatic grasses - Leaf anatomy · Luziolinae · Oryzeae $\cdot$ Poales $\cdot$ Zizaniinae

\section{Introduction}

The subfamily Oryzoideae (syn. Ehrhartoideae) is monophyletic and a member of the BOP clade [Bambusoideae + Oryzoideae + Pooideae] of grasses (Grass Phylogeny Working Group (GPWG) II 2012; Soreng et al. 2015). Oryzoideae (excluding Streptogyneae) share a combination of characters including spikelets with two glumes (developed to reduced), one or two sterile lemmas, and a single fertile floret (whether bisexual or unisexual) (GPWG 2001; Terrell et al. 2001).

Oryzeae is one of four tribes classified within Oryzoideae and comprises 13 genera (Soreng et al. 2015) with about 70 species that occur mostly in aquatic environments. Currently, Oryzeae is subdivided into two subtribes (Oryzinae and Zizaniinae) based on morphological, anatomical, embryological and molecular analyses (Duvall et al. 1993; Soreng et al. 2015). Zizaniinae (syn. Luziolinae-Terrell and Robinson 1974) comprises nine genera, including Luziola Juss.

Luziola consists of nine aquatic, monoecious, perennial species, distributed from North America to Argentina, with its center of diversity in South America (Swallen 1965; Terrell and Duvall 2000), where all nine species occur in Brazil (Filgueiras et al. 2015).

The Pantanal is characterized by a heterogeneous vegetation community, which is shaped by periodic flooding (Adámoli and Pott 1996), where five Luziola species 
Table 1 Species and vouchers for the micromorphological and anatomical studies of Luziola

\begin{tabular}{llll}
\hline Species & State and locality of collection & Collector & CGMS voucher \\
\hline Luziola bahiensis & MS-Corguinho & A. Guglieri 1610 & 20.889 \\
& MS-Alcinópolis & V. J. Pott 10200 & 22.681 \\
& MS-Alcinópolis & V. J. Pott 10238 & 22.719 \\
Luziola fragilis & MS-Porto Murtinho & A. Guglieri 2432 & 26.845 \\
& MS-Terenos & S. N. Moreira 173 & 23.636 \\
Luziola peruviana & MS-Corumbá & A. Guglieri 2099 & 26.185 \\
& MS-Corumbá & A. Guglieri 2100 & 26.186 \\
Luziola spruceana & MS-Corumbá & S. N. Moreira 249 & 27.248 \\
& MS-Corumbá & R. H. Silva 43 & 28.339 \\
Luziola subintegra & MS-Corumbá & L. S. Rodrigues 22 & 24.973 \\
& MS-Corumbá & L. S. Rodrigues 31 & 24.983 \\
& MS-Corumbá & F. S. Carvalho 326 & 29.015
\end{tabular}

MS Mato Grosso do Sul State, Brazil exhibit important ecological adaptations to the periodic flooding typical of this tropical wetland. Luziola bahiensis (Steud.) Hitchc. is considered an occasionally aquatic species (Albuquerque 1981) which is shade tolerant and highly sensitive to drought and fire (Pott and Pott 2000). Also, Luziola bahiensis as well as L. peruviana Juss. ex J.F.Gmel. are invasive to native populations of rice (Oryza glumaepatula Steud. and O. latifolia Desv.) (Kissmann 1997). Luziola fragilis Swallen and L. peruviana are generally found in standing water, mainly in the ponds ("baías"), temporary ponds, and floodable grasslands (Pott and Pott 2000). Furthermore, Luziola peruviana may establish as emergent, floating or submerged, while $L$. fragilis usually colonizes areas impacted by anthropogenic activities, such as borrow pits-common in the Pantanal for water storage during the dry seasonal (Pott and Pott 2000). Luziola spruceana Benth. ex Doell and L. subintegra Swallen resemble native rice when in the vegetative stage, and are usually dispersed by floating mats ("baceiros") when seasonal streams are present (Pott and Pott 2000).

The strongly similar morphological features of Luziola species in the vegetative stage raised the need for systematic and phylogenetic studies to the genus (Martinez-yPerez et al. 2006a, b, 2008). Although surveys of anatomy of the leaf blade have revealed the utility of features in the delimitation of Poaceae (e.g., Metcalfe 1960; Tateoka 1963; Vieira et al. 2002; Guglieri et al. 2008; Pelegrin et al. 2009; Jesus-Junior et al. 2012), there is a dearth of information particularly among morphologically similar grasses in the vegetative stage.

Due to the morphological affinity and importance of correct delimitation of Luziola species in the vegetative stage, the aim of this work was to study leaf blade micromorphology and anatomy of Luziola bahiensis, $L$. fragilis, L. peruviana, L. spruceana and $L$. subintegra, effectively mapping useful features for the identification of taxa and to contribute towards future anatomical characterization of the genus.

\section{Materials and methods}

\section{Sampling}

The following five species of Luziola from the Pantanal, Brazil were studied: L. bahiensis, L. fragilis, L. peruviana, $L$. spruceana and $L$. subintegra. Due to the difficulty in finding reproductive stages in the field, for this work we studied only dry material from the CGMS herbarium collection to ensure the species identification (Table 1). Also, since Luziola species occur in environments with seasonal variation in water availability, this study was carried out with at least three specimens for each species (when possible) collected during different growing seasons (dry, moist or flood conditions). Our sampling was limited to the five species in the State of Mato Grosso do Sul because a parallel study was being carried out for the other four species of Luziola in the State of Bahia (K. R. B. Leite personal comm.).

\section{Leaf blade analysis}

For SEM description of the silicified structures (trichomes and silica bodies), one fragment of approximately $0.5 \mathrm{~cm}^{2}$ of the middle portion of the leaf blade from the third stem node was removed from dry material. The fragment was carbonized at $200{ }^{\circ} \mathrm{C}$, washed with sulphuric acid, later rinsed with distilled water to eliminate formed chloride and then, left to dry at room temperature (Figueiredo and Handro 1971). This dried material was also carbonized (at $800{ }^{\circ} \mathrm{C}$ ). The resulting powder from the incineration was 
fixed in a cylindrical sample holder (stub) and coated with a thin sample of gold (Denton vacuum Desk III). For SEM description of the leaf blade surface, two fragments of approximately $0.5 \mathrm{~cm}^{2}$ of the same portion of the leaf blade representing adaxial and abaxial surfaces were removed from dry material, fixed on stubs, and also coated with a thin sample of gold. Observation and images were obtained with the aid of a scanning electron microscope (JEOL JSM-6380LV).

For anatomical study, fully expanded leaf blades were taken from the third stem node and sectioned at the middle portion. Each sample was immersed in a rewetting solution containing distilled water, ethanol, glycerin, and neutral detergent (Guglieri et al. 2008). The mixture was placed in an incubator at $60{ }^{\circ} \mathrm{C}$ for 3 days, after which samples were removed and stored in $70 \%$ alcohol. The sample pieces were placed in polyethylene glycol 1.500 solution (adapted from Richter 1985) and cross and longitudinal sections were made using a Leica RM 2145 rotary microtome. The sections were diaphonized in $50 \%$ sodium hypochlorite, rinsed in distilled water, and stained in Astra Blue and Safranin (Roeser 1972). Semi-permanent slides were mounted in $50 \%$ glycerin, and analyzed under a light microscope (Olympus CX-41F).

Photomicrographs were obtained with the aid of the microscope (Leica DM 5500B) through the Leica Suite Application 3.8.0 software. The terminology for the leaf blade in cross section and in surface view primarily followed Ellis (1976, 1979), with subsequent updates to mesophyll terminology in Poaceae (Sanchez-Ken et al. 2001).

\section{Results}

Intraspecific anatomical variation, such as the area of the air gaps, tissue lignification, and trichome density were found for all species studied. Despite these variations, there are no intraspecific interference effects to identify these species, since all exhibit similar intraspecific micromorphological and anatomical characteristics. The main features of the micromorphology and anatomy of the leaf blade, useful to identification and delimitation of studied Luziola species, are summarized in Table 2.

\section{Micromorphology (SEM)}

In surface view, the epidermis of all species has alternating long and short cells. The long cells are tabular shaped in the costal zone and mostly hexagonal in the intercostal zone (Figs. 1, 2). These cells present silicified outer walls with conical papillae densely covered by epicuticular rod-shaped wax, as in Luziola bahiensis (Figs. 1a, b, 2a). Short cells that develop as silica cells have dumbbell (Figs. 1b, 2c) or crossshaped silica bodies (Fig. 1c, f-i, 2g-h, k-1). Dumbbell silica bodies are inserted parallel to the long axis of the leaf as seen in Luziola bahiensis (Fig. 1b). On the other hand, Luziola fragilis (Figs. 1d, 2g), L. peruviana (Figs. 1f, 2h), L. spruceana (Figs. 1g-h, 2k), and L. subintegra (Figs. 1i, 2l) have cross-shaped silica bodies that are inserted perpendicular to the long axis of the leaf blade (Table 2). Luziola fragilis (Fig. 1c) and L. peruviana (Fig. 1e) have epidermal furrows in the adaxial surface (Table 2).

Table 2 Main micromorphological and anatomical features of the leaf blade distinguishable among the studied Luziola species

\begin{tabular}{|c|c|c|c|c|c|}
\hline \multirow[b]{2}{*}{ Features } & \multicolumn{5}{|c|}{ SPECIES } \\
\hline & L. bahiensis & L. fragilis & L. peruviana & L. spruceana & L. subintegra \\
\hline \multicolumn{6}{|l|}{ Epidermis (surface view) } \\
\hline Vertically elongated cells surrounding pointed unicellular trichomes & - & + & - & - & - \\
\hline Stomata in the epidermal furrows on the adaxial surface & - & + & + & - & - \\
\hline Oryzoid-type silica bodies & - & + & + & + & + \\
\hline \multicolumn{6}{|l|}{ Mesophyll (cross-section) } \\
\hline Fusoid cells & - & - & - & + & + \\
\hline Superposed vascular bundles & - & - & - & + & + \\
\hline Dimorphism between leaf blade margins (within the same sample) & - & + & - & - & - \\
\hline Obtuse margins & - & - & - & - & + \\
\hline \multicolumn{6}{|l|}{ Midrib (cross-section) } \\
\hline Flat & - & + & - & - & - \\
\hline Composed by more than two vascular bundles & - & - & - & + & + \\
\hline
\end{tabular}

+ Presence; ${ }^{-}$Absence; squares indicate exclusive features of particular species 
T. D. Leandro et al.
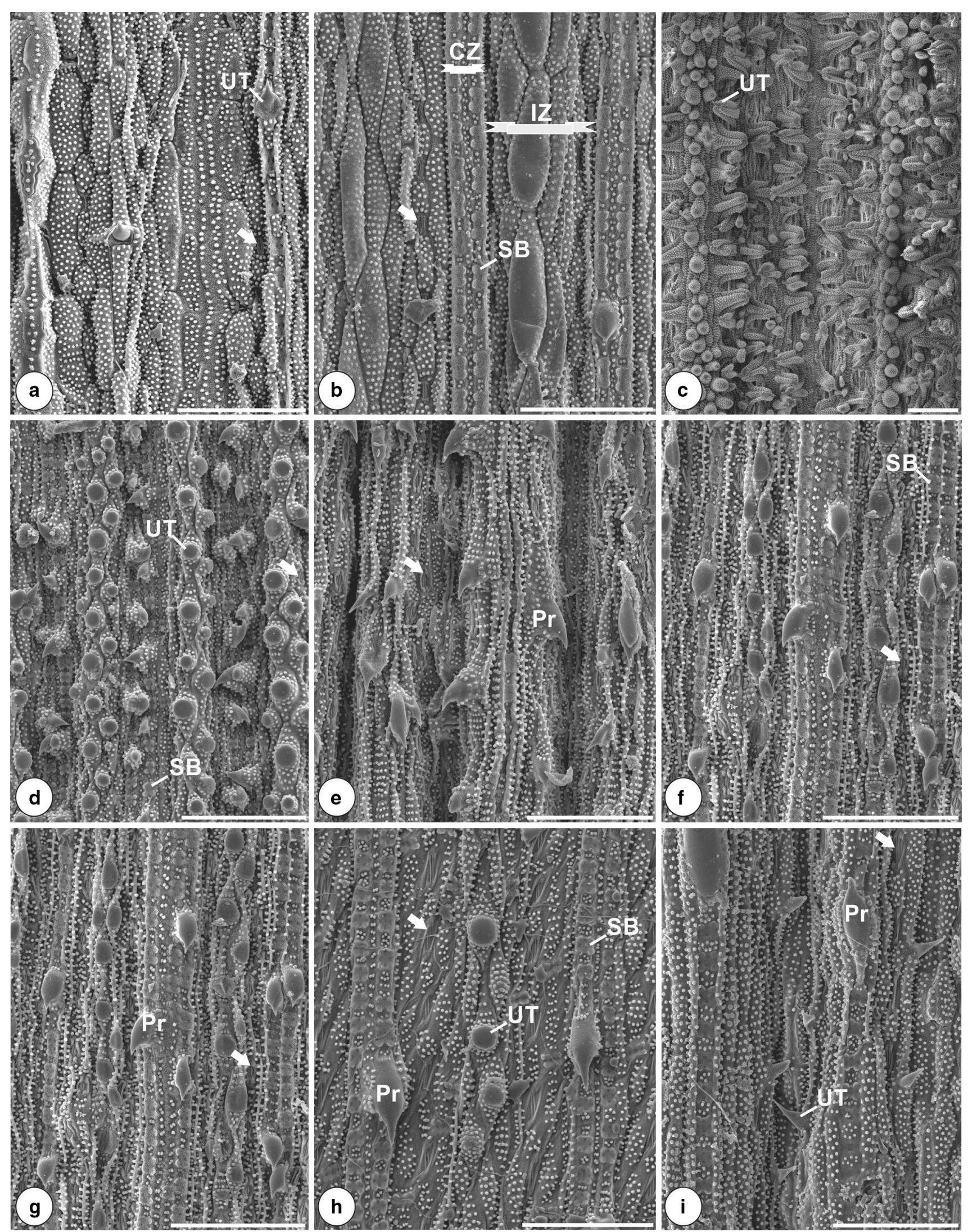
4Fig. 1 Micromorphology of the leaf blade of Luziola species in surface view. Adaxial surface $(\mathbf{a}, \mathbf{c}, \mathbf{e}, \mathbf{g}, \mathbf{i})$, abaxial surface $(\mathbf{b}, \mathbf{d}, \mathbf{f}, \mathbf{h}) . \mathbf{a}, \mathbf{b} L$. bahiensis; c, d $L$. fragilis; $\mathbf{e , ~} \mathbf{f} L$. peruviana; $\mathbf{g}, \mathbf{h} L$. spruceana; $\mathbf{i} L$. subintegra. $C Z$ costal zone, $I Z$ intercostal zone, $\operatorname{Pr}$ prickle hair, $S B$ silica bodies, UT unicellular trichome. Arrows the stomata. Scale bars $100 \mu \mathrm{m}$

Stomata are paracytic with subsidiary cells which are low dome-shaped forming a narrow stomatal complex (e.g., Fig. 2b, d). Trichomes can be of three types: unicellular silicified with a (1) pointed or (2) rounded apex, and (3) prickles. The pointed trichomes occur on the adaxial surface in L. bahiensis (Fig. 1a), adaxial and abaxial surfaces in L. fragilis (Figs. 1c, d, 2b, f, i) and the adaxial surface in L. subintegra (Fig. 1i), while the rounded-apex trichomes occur on the adaxial and abaxial surfaces of $L$. fragilis (Fig. 1d) and on the abaxial surface of L. spruceana (Fig. 1h). Prickle hairs, short and silicified unicellular trichomes (Fig. 2e), are observed in the costal zone of both surfaces of the leaf blade in most species (e.g., Fig. 1f-g), except in L. fragilis (Fig. 1d) and L. spruceana (Fig. 1h), where they occur only on the abaxial surface. Epidermal cells form vertically elongated outgrowths which partially cover the pointed trichomes in L. fragilis (Figs. 1c, d, 2f, i; Table 2) and the rounded trichomes in $L$. spruceana (Fig. 1h).

With regard to the leaf blade margins, only Luziola fragilis has micromorphological dimorphism within the same sample, where pointed trichomes may be present (Fig. 2i) or absent (Fig. 2j), as well as vertical outgrowths (Fig. 2i).
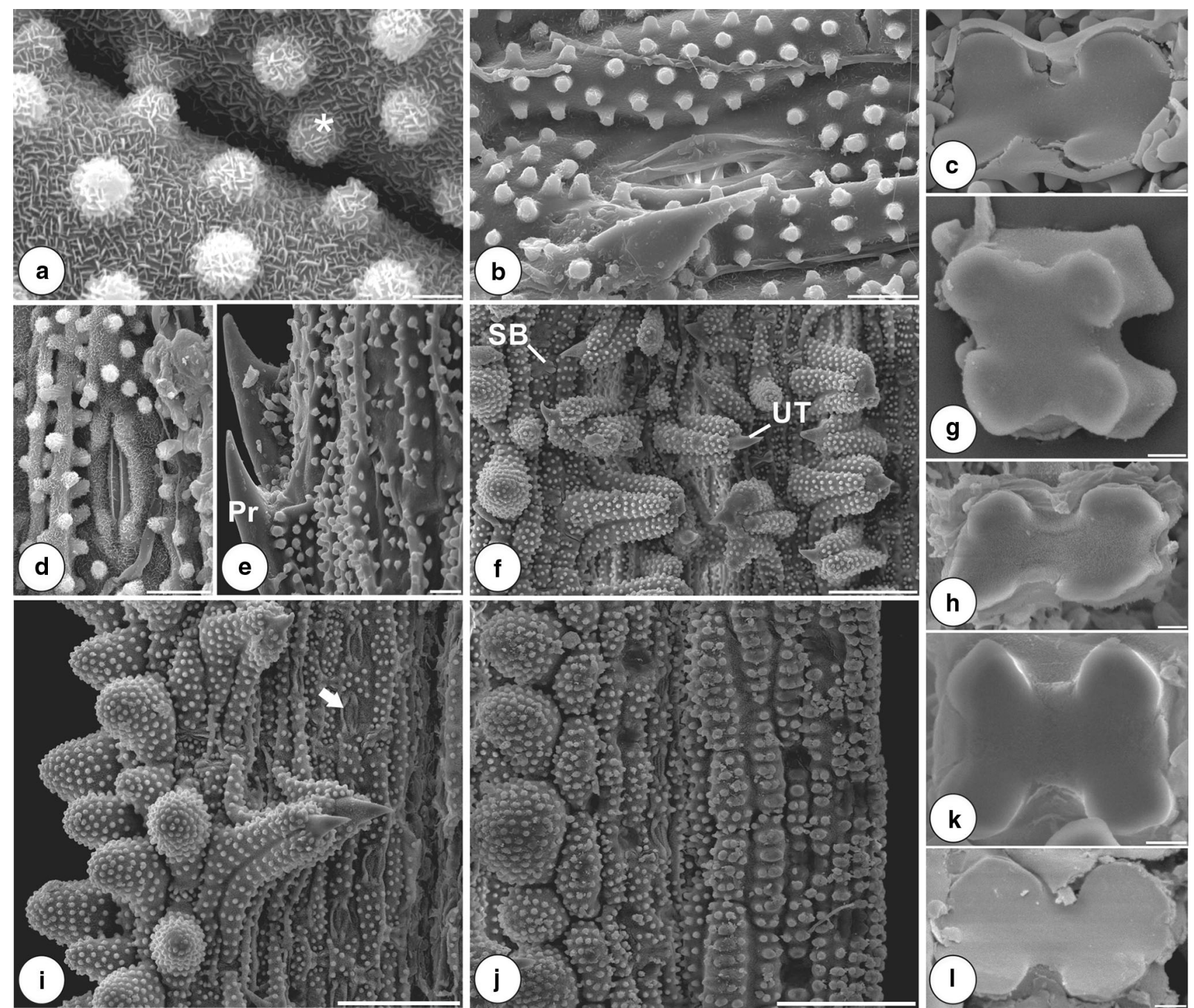

Fig. 2 Micromorphology of the leaf blade of Luziola species. Adaxial surface $(\mathbf{a}, \mathbf{f})$, abaxial surface $(\mathbf{b})$ and silica bodies $(\mathbf{c}, \mathbf{g}, \mathbf{h}, \mathbf{k}, \mathbf{l})$. a $L$. bahiensis; $\mathbf{b}$ L. fragilis; $\mathbf{c}$ L. bahiensis; $\mathbf{d}$ L. peruviana; $\mathbf{e}$ L. subintegra; $\mathbf{f}$, $\mathbf{g}$ L. fragilis; $\mathbf{h}$ L. peruviana; $\mathbf{i}$ and $\mathbf{j}$ L. fragilis showing the comparison of the leaf blade margins; $\mathbf{k}$ L. spruceana; $\mathbf{l}$ L. subintegra. Pr prickle, $S B$ silica bodies, UT unicellular trichome. Arrow stomata and asterisk conical papillae with epicuticular rod-shaped wax. Scale bars $2 \mu \mathrm{m}(\mathbf{a}$, $\mathbf{c}, \mathbf{g}, \mathbf{h}, \mathbf{k}, \mathbf{l}) ; 10 \mu \mathrm{m}(\mathbf{b}) ; 50 \mu \mathrm{m}(\mathbf{f}, \mathbf{i}, \mathbf{j})$ 

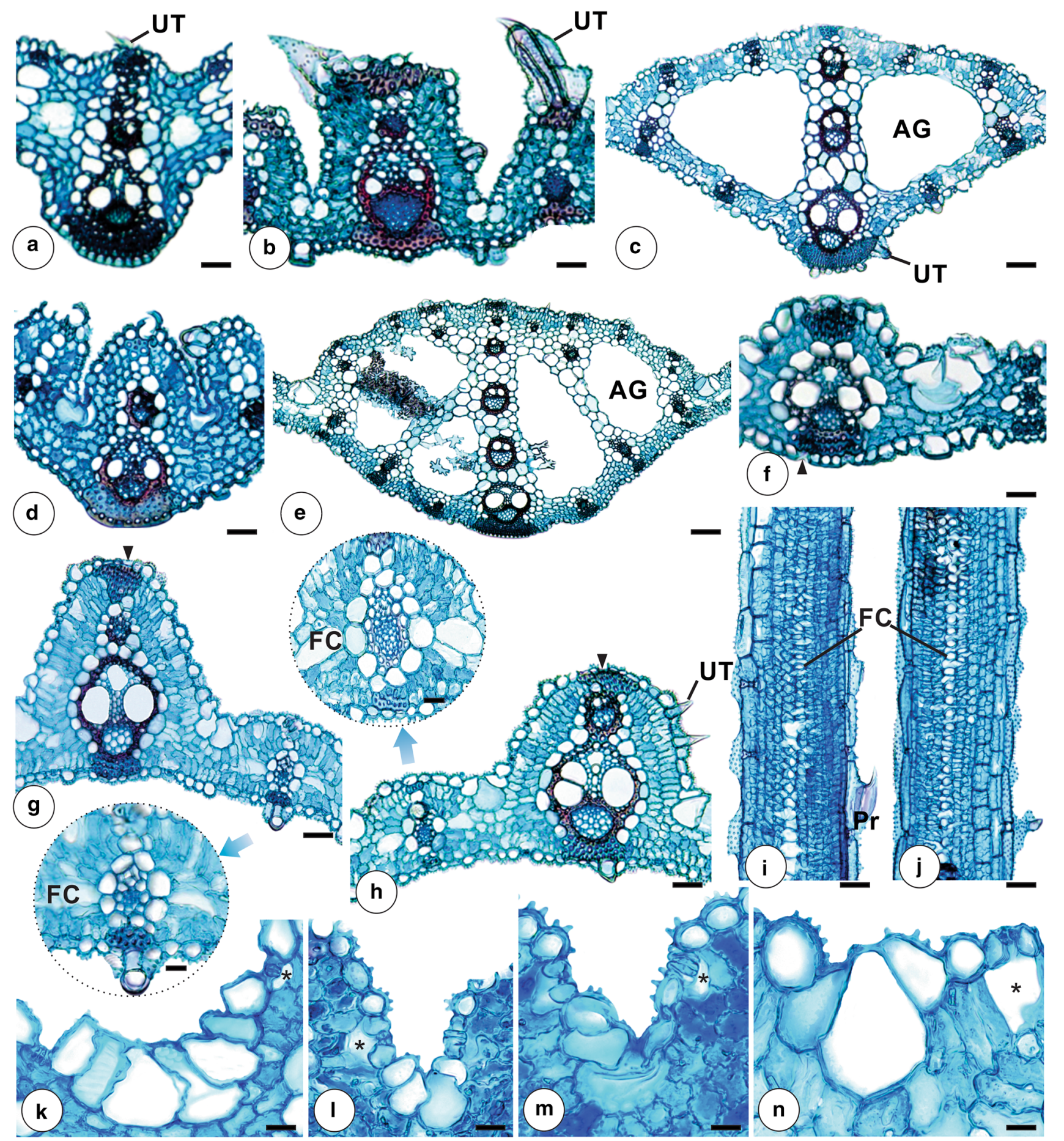

Fig. 3 Leaf blade anatomy of Luziola species. Cross section $(\mathbf{a}-\mathbf{h}, \mathbf{k}-$ n) and longitudinal section (i, j). a L. bahiensis; b L. fragilis; $\mathbf{c} L$. spruceana; d $L$. peruviana; e $L$. subintegra; f $L$. bahiensis; $\mathbf{g} L$. spruceana and $\mathbf{h} L$. subintegra both showing superposed vascular bundles in the mesophyll and detail of the vascular bundle adjacent to

\section{Cross section (light microscopy)}

The epidermis in cross section of all species consists of a single stratum of cells, with visible thickening of the

fusoid cells; i L. spruceana; j L. subintegra; $\mathbf{k}$ L. bahiensis; 1 L. fragilis; $\mathbf{m}$ L. peruviana; $\mathbf{n} L$. spruceana. $A G$ air gap, $F C$ fusoid cells, UT unicellular trichome. Arrowheads in $(\mathbf{f}, \mathbf{g}, \mathbf{h})$ indicate silica bodies. Scale bars $10 \mu \mathrm{m}(\mathbf{k}, \mathbf{l}, \mathbf{m}, \mathbf{n}) ; 25 \mu \mathrm{m}$ (g detail, $\mathbf{h}$ detail); 50 $\mu \mathrm{m}(\mathbf{a}, \mathbf{b}, \mathbf{d}, \mathbf{f}-\mathbf{j}) ; 100 \mu \mathrm{m}(\mathbf{c}, \mathbf{e})$

external periclinal wall (Fig. 3). Along both surfaces conical papillae are noticeable (Figs. 3f-h, k-n, 4). All species possess amphistomatic leaf blades with associated substomatal chambers (Fig. 3k-n, asterisks). In both L. fragilis 
(Fig. 3b) and L. peruviana (Fig. 3d) the adaxial stomata occur in epidermal furrows. Stomata are mainly situated slightly below the epidermal surface (Fig. $3 \mathrm{k}-\mathrm{n}$ ) in all species. Fan-shaped arrays of bulliform cells are situated only in the adaxial surface above the level of other epidermal cells in all species (Fig. 3k-n).

The mesophyll is formed mainly by rosette cells containing chloroplasts and vascular bundles (Fig. 3a-n). The rosette cells are lobed mostly at the same depth all the way around, mostly oriented horizontally to the epidermis (Fig. 3a-h) and radially around the vascular bundles, more visibly so in $L$. spruceana (Fig. $3 g$ ) and $L$. subintegra (Fig. 3h). Fusoid cells occur in L. spruceana (Fig. 3g, g detail, i) and L. subintegra (Fig. $3 \mathrm{~h}, \mathrm{~h}$ detail and $\mathrm{j}$ ), between vascular bundles and adjacent to the chlorenchyma cells (Table 2).

Vascular bundles are collateral, with conducting elements surrounded by a double sheath, the inner mestome sheath (pericyclic) and the outer parenchymatous sheath (endodermis) (e.g., Fig. 3a). All species have both firstand third-order vascular bundles in the mesophyll, as in $L$. bahiensis (Fig. 3f). Luziola spruceana (Fig. 3g) and $L$. subintegra (Fig. 3h) possess, in the midrib and throughout the leaf blade, sets of a second-order vascular bundle opposed to a first-order one (Table 2) both sharing the same parenchymatous sheath. All the sets of first- and third-order vascular bundles have adaxial and abaxial girders, usually abaxially interrupting the parenchymatous sheath, as seen in Luziola bahiensis (Fig. 3f).

The midrib in most species is distinguished by the presence of an abaxial keel (Fig. 3a, c-e), whereas a flat midrib is seen only in L. fragilis (Fig. 3b; Table 2). The number of bundles comprising the midrib varies, with two in L. bahiensis (Fig. 3a), L. fragilis (Fig. 3b) and $L$. peruviana (Fig. 3d) and several vascular bundles of different sizes in $L$. spruceana (Fig. $3 \mathrm{c}$ ) and L. subintegra (Fig. 3e; Table 2). In this region, three and five vascular bundles are superposed in a column in $L$. spruceana (Fig. 3c) and L. subintegra (Fig. 3e), respectively. The other three species have two superposed vascular bundles in the midrib, as in L. fragilis (Fig. 3b). Air gaps occur in the midrib of most species, except L. fragilis (Fig. 3b) and $L$. peruviana (Fig. $3 \mathrm{~d}$ ).

The leaf margins are acute for most of the species (e.g., Fig. 4a-c), except in L. subintegra which possesses obtuse margins (Fig. 4d; Table 2). All species exhibit thickened epidermal cells in this region and sclerenchyma fibers below the epidermis (Fig. 4). Dimorphism of the leaf blade margin within the same sample was also observed in the cross sections of $L$. fragilis, mainly concerning the thickness and number of the sclerenchyma cells (Fig. 4b, c).

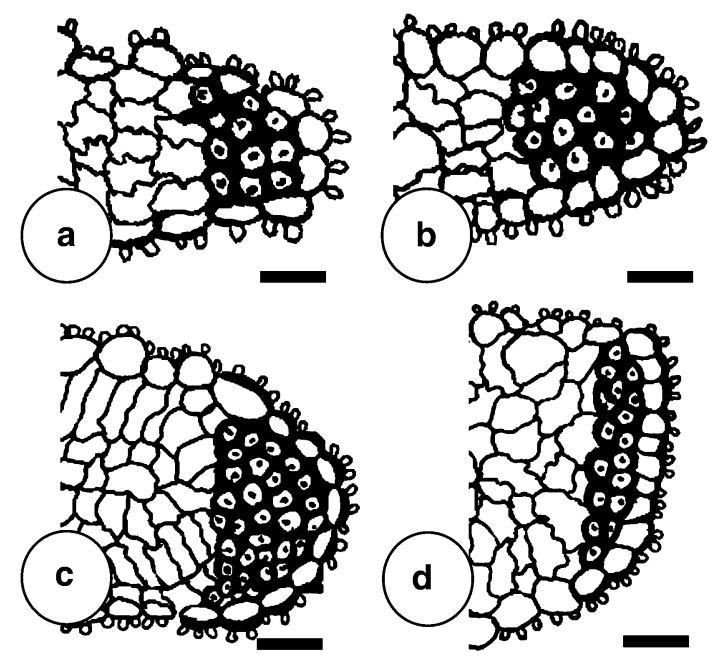

Fig. 4 Anatomy of the leaf blade margin of Luziola species in cross section. Acute margins $(\mathbf{a}-\mathbf{c})$, obtuse margins $(\mathbf{d})$. a, b $L$. fragilis; $\mathbf{c} L$. spruceana; d L. subintegra. Scale bars $25 \mu \mathrm{m}$

\section{Discussion}

Some observed features in Luziola species are common for Oryzoideae, such as the epidermis with silicified outer walls and wax impregnation, fan-shaped arrays of bulliform cells on the adaxial surface, collateral vascular bundles surrounded by a double sheath, and long cells with multiple papillae (Metcalfe 1960; Tateoka 1963; Renvoize 1985; Piperno and Pearsall 1998; Sánchez et al. 2003, 2006; Sánchez and Espinoza 2005). Luziola species also share features consistent with Oryzeae, such as oryzoid silica bodies, mesophyll with rosette cells [previously classified as arm cells by Ellis (1976)], and a complex midrib (Metcalfe 1960; Tateoka 1963; Pyrah 1967; Holm 1895).

Although rosette cells in the mesophyll and oryzoid silica bodies are two important features for recognizing Oryzeae, there are variations among the taxa within this tribe. Rosette cells are absent from the mesophyll in most oryzoids from Eurasia (Chikusichloa Koidz., Hygroryza Nees) and differences in the shape of the silica bodies is reported within Oryzeae species (Tateoka 1963). Despite the variation in shape, concerning the type of insertion of the silica bodies throughout the leaf blade, the presence of oryzoid-type silica bodies is a diagnostic feature only for oryzoids (Tateoka 1963; Ellis 1979; Prasad et al. 2005, 2011), and therefore, it is a useful characteristic for recognizing at least Oryzeae species.

The complex midrib as seen in Luziola and other genera of Oryzeae that includes at least two vascular bundles near to the abaxial surface (de Winter 1951; Tateoka 1963; Pyrah 1967; Renvoize 1985), seems to be a strong and 
distinctive feature between this tribe and Ehrharteae, which possesses only one vascular bundle in the midrib. Since the complex midrib is an important feature to delimit bamboo subtribes (BPG 2012), we need to mention that the complex midrib herein described is the only feature shared by all five species studied; therefore, potentially serving as a synapomorphy for Luziola or perhaps for the tribe Oryzeae-except for Hygroryza, which possesses a simple midrib. However, midrib structure in the other four species must be examined before any conclusions are possible. In addition, superposed mesophyll vascular bundles shared between $L$. spruceana and L. subintegra deserves more attention in future work with the anatomy of Oryzeae, since this feature seems unusual in Poaceae; to our knowledge, this is the first report for the grass family.

Another important feature also deserves attention. The vertically elongated epidermal cells surrounding unicellular trichomes, unique to L. fragilis, have not been previously described from any other grass species. We were not able to ascertain how these cells assume this characteristic or what function they may serve, thus we recommend an ontogenetic study to further explore this unique feature.

Fusoid cells are characteristic of Bambusoideae and the early diverging lineages, and thus are plesiomorphic within the Poaceae (GPWG 2001). Qualitative studies that report the presence or absence of these cells in the mesophyll of bamboos are common and taxonomically useful (e.g., Guala 1995; Oliveira et al. 2008; Leandro et al. 2016). Although the presence of fusoid cells has been a useful feature for species identification and delimitation, it is worth calling attention to the influence of light on the presence or absence of these cells. March and Clark (2011) compared the leaf blade anatomy in sun and shade leaves of bamboos, where leaves with and lacking fusoid cells were found even on the same plant, with the outermost leaves lacking fusoid cells. The influence of light and the function of fusoid cells are not yet clear, nonetheless, the presence of these cells in Luziola spruceana and $L$. subintegra is an important report toward understanding their occurrence and importance for Poaceae, since these species occur in open habitats.

Some xerophytic features, such as the epidermal furrows seen in L. fragilis and L. peruviana, would normally be expected in plants of more arid habitats (Oppenheimer 1960), rather than an aquatic plant. This feature may be a consequence of the establishment of these species in sites with variations of water availability, such as temporary ponds.

The results presented here show that the studied Luziola species possess consistent micromorphological and anatomical features of the leaf blade for the identification and delimitation of the taxa. Luziola spruceana and $L$. subintegra show the greatest morphoanatomical affinity, whereas L. fragilis shows the greatest number of exclusive features. Luziola peruviana shows only features common to all the other studied species. The results of the work by K. R. B. Leite are being prepared, and a combined analysis of the micromorphological and anatomical data for the entire genus is being planned, with the goals of characterizing the genus and understanding the evolution of anatomical and micromorphological features of the leaf blade within Luziola.

\section{Taxonomic treatment}

\section{Key to the species of Luziola present in the Pantanal, Brazil, based on micromorphological and anatomical features}

1a. Epidermis with vertically elongated cells surrounding pointed unicellular trichomes; midrib flat; leaf blade margins dimorphic ....................... L. fragilis

1b.Epidermis without vertically elongated cells surrounding pointed unicellular trichomes; midrib with an abaxial keel; leaf blade margins structurally similar ................................................ 2

2a. Superposed vascular bundles in the mesophyll present; midrib composed of more than two vascular bundles; fusoid cells present ...................................... 3

2b. Superposed vascular bundles in the mesophyll absent; midrib composed of two vascular bundles; fusoid cells absent ........................................... 4

3a. Midrib with three vascular bundles superposed in a column; up to two air gaps .............. L. spruceana

3b. Midrib with five vascular bundles superposed in a column; more than two air gaps ............. L. subintegra

4a. Adaxial surface of the leaf blade with deep epidermal furrows; midrib with air gaps ............ L. peruviana

4b. Adaxial surface of the leaf blade without epidermal furrows; midrib without air gaps ........ L. bahiensis

Acknowledgments The authors are grateful to the curators of the CGMS Herbarium/UFMS for the donation of material; V Manvailer for assistance with image processing; LF Plaça for assistance with generating SEM micrographs, captured at the Multiuser Laboratory of Scanning Electron Microscopy/UFMS. The authors thank PNADB/ CAPES and CNPq (process numbers: 308793/2013-7 and $311267 / 2012-2$ ) for financial support. We also thank an anonymous referee and TJ Gallaher for comments that greatly improved the manuscript.

\section{References}

Adámoli J, Pott A (1996) Caracterizacion ecologica y fitosociologica del Pantanal de Paiaguás. In: Sarmiento G, Cabido M (eds) 
Caracterizacion ecologica y fitosociologica del Pantanal de Paiaguás. CYTED/CIELAT, Mérida, pp 197-201

Albuquerque EWP (1981) Plantas forrageiras da Amazônia. 1-Aquáticas flutuantes livres. Acta Amazon 11:457-471

Bamboo Phylogeny Group (BPG) (2012) An updated tribal and subtribal classification of the bamboos (Poaceae: Bambusoideae). J Amer Bamboo Soc 24:1-10

de Winter B (1951) A morphological, anatomical and cytological study of Potamophila prehensilis (Ness) Benth. Bothalia 6:117-137. doi10.4102/abc.v6i1.1682

Duvall MR, Peterson PM, Terrell EE, Christensen AH (1993) Phylogeny of North American oryzoid grasses as construed from maps of plastid DNA restriction sites. Amer J Bot 80:83-88

Ellis RP (1976) A procedure for standardizing comparative leaf anatomy in the Poaceae I. The leaf-blade as viewed in transverse section. Bothalia 12:65-109. doi:10.4102/abc.v12i1.1382

Ellis RP (1979) A procedure for standardizing comparative leaf anatomy in the Poaceae II. The epidermis as seen in surface view. Bothalia 12:641-671. doi:10.4102/abc.v12i4.1441

Figueiredo RCL, Handro W (1971) Corpos silicosos de gramíneas dos cerrados V. In: Ferri MG (ed) III Simpósio sobre o Cerrado. Editora Edgard Blücher, Sao Paulo, pp 215-230

Filgueiras TS, Valls JFM, Dórea MC, Oliveira RP (2015) Luziola in Lista de Espécies da Flora do Brasil. Jardim Botânico do Rio de Janeiro. Available at: http://reflora.jbrj.gov.br/jabot/floradobra sil/FB13309. Accessed 2 Jul 2015

Grass Phylogeny Working Group (GPWG) (2001) Phylogeny and subfamilial classification of the grasses (Poaceae). Ann Missouri Bot Gard 88:373-456

Grass Phylogeny Working Group (GPWG) (2012) New grass phylogeny resolves deep evolutionary relationships and discovers C4 origins. New Phytol 193:304-312. doi:10.1111/j.14698137.2011.03972.x

Guala FG (1995) A cladistic analysis and revision of the genus Apoclada (Poaceae: Bambusoideae: Bambusoidae). Syst Bot 20:207-223

Guglieri A, Longhi-Wagner HM, Zuloaga FO (2008) Anatomia foliar das espécies de Panicum L. subg. Panicum (Poaceae: Panicoideae: Paniceae) no Brasil. Iheringia Bot 63:279-293

Holm T (1895) A study of some anatomical characters of North American Gramineae V. Bot Gaz 20:362-365

Jesus-Junior LA, Oliveira RP, Leite KRB, Silva LB (2012) Comparative analysis of the leaf anatomy in two Parodiolyra species (Poaceae: Olyreae) occuring on forests in Eastern Brazil. Brazil J Biol 72:205-210. doi:10.1590/S1519-69842012000100025

Kissmann KG (1997) Plantas infestantes e nocivas, 2nd edn. BASF, São Paulo

Leandro TD, Shirasuna RT, Filgueiras TS, Scatena VL (2016) The utility of Bambusoideae (Poaceae, Poales) leaf blade anatomy for identification and systematics. Brazil J Biol 76 (accepted)

March RH, Clark LG (2011) Sun-shade variation in bamboo (Poaceae: Bambusoideae) leaves. Telopea 13:93-104

Martinéz-y-Pérez JL, Mejía-Saulés T, Sosa V (2008) A taxonomic revision of Luziola (Poaceae: Oryzeae). Syst Bot 33:702-708. doi:10.1600/036364408786500226

Martínez-y-Perez JL, Mejia-Saules T, Sosa V (2006a) Phylogenetic relationships of Luziola (Poaceae: Oryzeae) and related genera from aquatic habitats. Canad J Bot 84:1753-1770. doi:10.1139/b06-123

Martinez-y-Perez JL, Sosa V, Meija-Saules T (2006b) Species delimitation in the Luziola peruviana (Poaceae) complex. Brittonia 58(4):362-375. doi:10.1663/0007-196X(2006)58[362: SDITLP]2.0.CO;2

Metcalfe CR (1960) Anatomy of the monocotyledons I: Gramineae. Claredon Press, Oxford

Oliveira RP, Longhi-Wagner HM, Leite KRB (2008) A contribuição da anatomia foliar para a taxonomia de Raddia Bertol. (Poaceae:
Bambusoideae). Acta Bot Brasil 22:1-19. doi:10.1590/S010233062008000100002

Oppenheimer HR (1960) Adaptation to drought: xerophytism. Arid Zone Res (Beijing) 15:105-138

Pelegrin CMG, Longhi-Wagner HM, Oliveira PL (2009) Anatomia foliar como subsídio à taxonomia de espécies do Complexo Briza L. (Poaceae: Pooideae: Poeae). Acta Bot Brasil 23:666-680. doi:10.1590/S0102-33062009000300006

Piperno DR, Pearsall DM (1998) The silica bodies of Tropical American Grasses: morphology, taxonomy, and implications for grass systematic and fossil phytolith identification. Smithsonian Institution Press, Washington, DC

Pott VJ, Pott A (2000) Plantas aquáticas do Pantanal. Brasília, Embrapa

Prasad V, Strömberg CAE, Alimohammadian H, Shani A (2005) Dinosaur coprolites and the early evolution of grasses and grazers. Science 310:1177. doi:10.1126/science.1118806

Prasad V, Strömberg CAE, Leaché AD, Samant B, Patnaik R, Tang L, Mohabey DM, Ge S, Sahni A (2011) Late Cretaceous origin of the rice tribe provides evidence for early diversification in Poaceae. Nat Commun 2:480. doi:10.1038/ncomms1482

Pyrah GL (1967) Taxonomic and distributional studies in Leersia (Gramineae). PhD Dissertation. Iowa State University, Ames

Renvoize SA (1985) A survey of leaf-blade anatomy in grasses V. The bamboo allies. Kew Bull 40:509-535

Richter HG (1985) Wood and bark anatomy of Lauraceae II. Licaria Aublet. Iawa Bull 6:187-199

Roeser KR (1972) Die Nadel der Schwarzkiefer-Massenproduckt und Kunstwerk der Natur. Mikrokosmos 61:33-36

Sánchez E, Espinoza AM (2005) Description of the ultrastructure of Oryza glumaepatula, a wild rice species endemic of tropical America. Revista Biol Trop 53:15-22

Sánchez E, Montiel M, Espinoza AM (2003) Ultraestructural morphologic description of the wild rice species Oryza latifolia (Poaceae) in Costa Rica. Revista Biol Trop 51:345-354

Sánchez E, Quesada T, Espinoza AM (2006) Ultrastructure of the wild rice Oryza grandiglumis (Gramineae) in Costa Rica. Revista Biol Trop 54:377-385

Sanchez-Ken JG, March RH, Clark LG (2001) Evolution of the mesophyll in the grasses (Poaceae). In: Anonymous (ed) Botany 2001, August 12-16, 2001. Albuquerque, New Mexico

Soreng RJ, Peterson PM, Komaschenko K, Davidse G, Zuloaga FO, Judziewicz EJ, Filgueiras TS, Davis JI, Morrone O (2015) A worldwide phylogenetic classification of the Poaceae (Gramineae). J Syst Evol 53:117-137. doi:10.1111/jse.12150

Swallen JR (1965) The grass genus Luziola. Ann Missouri Bot Gard $52: 472-475$

Tateoka T (1963) Notes on some grasses XII. Relationships between Oryzeae and Ehrharteae, with special reference to leaf anatomy and histology. Bot Gaz 124:264-270

Terrell EE, Duvall MR (2000) Luziola. In: Judziewicz EJ, Soreng RJ, Davidse G, Peterson PM, Filgueiras TS, Zuloaga FO (orgs) Catalogue of the New World Grasses (Poaceae) I. Subfamilies Anomochloideae, Bambusoideae, Ehrhartoideae and Pharoideae. Contr US Natl Herb 39:69-71

Terrell EE, Peterson PM, Wergin W (2001) Epidermal features and spikelet micromorphology in Oryza and related genera (Poaceae: Oryzeae). Smithsonian Contr Bot 91:1-50

Terrell EE, Robinson H (1974) Luziolinae, a new subtribe of oryzoid grasses. Bull Torrey Bot Club 101:235-245

Vieira RC, Gomes DMS, Sarahyba LS, Arruda RCO (2002) Leaf anatomy of three herbaceous bamboo species. Brazil J Biol 62:907-922. doi:10.1590/S1519-69842002000500021 